Jurnal KIBASP (Kajian Bahasa, Sastra dan Pengajaran)

Volume 1, Nomor 2, Juni 2018

e-ISSN : $2597-5218$

p-ISSN : 2597-520X

DOI: https://doi.org/10.31539/kibasp.v1i2.195

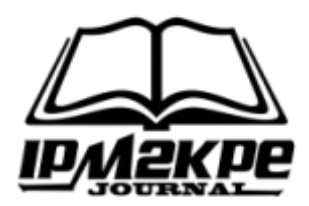

\title{
PENINGKATAN KEMAMPUAN MENULIS TEKS BERITA MELALUI METODE QUANTUM LEARNING DENGAN MEDIA GAMBAR SISWA KELAS VIII-E SMP NEGERI 17 SURABAYA
}

\author{
Tri Indriaty \\ SMP Negeri 17 Surabaya \\ triindriaty@gmail.com
}

Submit, 26-04-2018 Accepted, 25-06-2018 Publish, 27-06-2018

\begin{abstract}
ABSTRAK
Tujuan penelitian ini adalah untuk mengetahui peningkatan kemampuan menulis teks berita melalui metode quantum learning dengan menggunakan media gambar pada siswa kelas VIIIE SMP Negeri 17 Surabaya. Untuk mencapai sasaran penelitian dibutuhkan instrument antara lain: lembar observasi aktivitas guru, lembar observasi aktivitas siswa, dan hasil belajar siswa. Data yang diperoleh dalam penelitian ini disajikan dalam bentuk table dan dianalisis secara deskripsi. Pelaksanaan pembelajaran dilaksanakan dalam tiga siklus pembelajaran dan pada setiap siklusnya menunjukkan peningkatan aktivitas guru dan aktivitassiswa, nilai rata-rata siswa pada tiap siklusnya juga menunjukkan peningkatan jumlah nilai rata-rata, pada pembelajaran siklus pertama nilai rata-rata siswa ialah 62,92, nilai rata-rata siswa pada pembelajaran siklus kedua ialah 72 , pada pembelajaran siklus ketiga ialah 80, sehingga pembelajaran menulis berita melalui metode quantum learning dengan media gambar siklus pertama sampai dengan siklus ketiga menunjukkan peningkatan nilai rata-rata siswa.
\end{abstract}

Kata kunci: Menulis Teks Berita, Quantum Learning, Media Gambar.

\begin{abstract}
The purpose of this study is to determine the ability to write news text through the method of quantum learning by using the image media on the students of class VIIIE SMP Negeri 17 Surabaya. To achieve the objectives of research required instruments include: teacher activity observation sheets, student activity observation sheets, and student learning outcomes. The data obtained in this study is presented in table form and analyzed by description. Implementation of learning carried out in three learning cycles and in each cycle showed the increase of teacher activity and activity, the average value of students in each cycle also showed an increase in the number of average values, in the first cycle learning the average value of students is 62.92, the average of students in the second cycle of learning is 72, in the third cycle of learning is 80, so learning news writing through quantum learning method with the first cycle image media up to the third cycle shows the increase in the average value of students.
\end{abstract}

Keywords: Writing Text News, Quantum Learning, Picture Media. 


\section{PENDAHULUAN}

Pengajaran bahasa seharusnya tidak perpusat pada guru saja, tetapi harus berpusat juga pada siswa, yaitu siswa diharapkan dapat terlihat secara aktif dan kreatif dalam proses pembelajaran. Pengajaran bahasa juga harus dapat memotivasi siswa untuk belajar menciptakan kondisi agar siswa aktif merangkai pengetahuannya untuk memperoleh pengetahuannya yang baru. Proses belajar yang baik adalah proses yang berorientasi pada pendekatan keterampilan proses. Proses pembelajaran perlu dilakukan dengan tenang dan menyenangkan, hal tersebut menuntut guru untuk lebih kreatif dalam menciptakan lingkungan yang kondusif, proses pembelajaran dikatakan efektif apabila seluruh peserta didik terlibat secara aktif baik mental, fisik, maupun siosialnya.

Metode QuantumLearning adalah metode yang menggunakan pendekatan belajar yang mengutamakan percepatan belajar dengan cara partisipatori peserta didik dalam melihat potensi diri dalam kondisi penguasaan diri (Suyatno, 2004). Gaya belajar pada metode ini mengacu pada otak kanan dan otak kiri.Dalam metode ini kegembiraan dalam belajar dapat diperoleh dengan cara membangun emosi positif di dalam peserta didik, dengan cara seperti itu tentulah peserta didik dapat menghadirkan suasana gembira. Sedangkan menurut Bobbi De Porter dan Henarcki (2002) emosi positif dapat membuat otak bekerja secara maksimal. Untuk membangun emosi positif dalam belajar dapat menggunakan iringan musik. Dalam hal ini musik yang dianjurkan adalah musik barok, musik tersebut adalah sejenis musik klasik karena menurut De Porter dan Henarcki musik tersebut telah diteliti dan hasilnya menunjukkan bahwa musik tersebut mempunyai tempo yang sama dengan detak jantung rata-rata dalam keadaan normal, yaitu enam puluh ketukan per menit dengan adanya kegembiraan maka akan membuat setiap pembelajar menjadi menyenangkan, khususnya dalam keterampilan menulis.

Menurut Tarigan (1982) menulis adalah menurunkan atau melukiskan lambanglambang atau grafik yang menggambarkan suatu bahasa yang dapat dipahami oleh seseorang, sehingga orang lain dapat membaca lambang-lambang grafik tersebut. Dari keempat keterampilan berbahasa, keterampilan berbicara, dan keterampilan menulis merupakan salah satu jenis keterampilan yang dapat dibilang keterampilan yang paling produktif, tanpa memandang keterampilan yang lain tidak produktif. Menurut Tarigan 
(1982) tujuan dari pembelajaran menulis adalah pertama memberitahukan, kedua menghibur ketiga meyakinkan, mengutarakan atau mengekspresikan perasaan.

Fokus penelitiannya adalah usaha untuk meningkatkan kemampuan menulis khususnya pada karangan narasi melalui metode quantum dengan menggunakan kartu kata. Penelitian tersebut mencakup penerapan metode quantum dalam pembelajaran menulis narasi bermedia kartu kata, hasil belajar dari penerapan metodequantum bermedia kartu kata, dan respon siswa terhadap penerapan metode quantum bermedia kartu kata. Hasil penelitian menunjukkan bahwa dengan menggunakan metode quantum bermedia kartu kata pada pembelajaran menulis narasi dapat berjalan dengan lancer, serta hasil belajar siswa pun meningkat, dan respon siswa dalam mengikuti pembelajaran dengan metode quantum bermedia kartu kata ini pun positif. Berdasarkan latar belakang di atas, penulis tertarik untuk melakukan pendekatan dengan menggunakan metode quantum learning dalam pembelajaran menulis. Karena sering menjumpai masalah yang dihadapi siswa dalam pembelajaran menulis berita, khususnya dalam hal ini adalah pembelajaran menulis teks berita

\section{METODE PENELITIAN}

Penelitian yang akan dilakukan ini merupakan penelitian tindakan kelas. Penelitian ini menggunakan rancangan penelitian deskriptif kualitatif, karena dalam penelitian ini dihasilkan data deskriptif berupa kata-kata tertulis atau lisan dari beberapa siswa (Moleong, 2003). Karena penelitian ini berupa Penelitian Tindakan Kelas (PTK) maka pelaksanaan dalam penelitian ini akan dilakukan dalam tiga siklus pengajaran atau pembelajaran. Dalam tiap-tiap siklusnya akan mengikuti tahap atau proses sebagai berikut: Perencanaan, implementasi, dan observasi, refleksi, dan revisi. Subjek penelitian ini ialah siswa kelas VIIIE SMP Negeri 17 Surabaya yang berjumlah 34 siswa, yang terdiri dari 16 laki-laki dan 18 siswa perempuan. Dalam penelitian tindakan kelas ini dikumpulkan dengan teknik atau cara sebagai berikut.Observasi dan tes. Teknik analisis data yang digunakan yaitu:

1. Analisis Lembar Observasi. Lembar observasi merupakan suatu lembar yang diisi oleh guru pamong selama proses belajar berlangsung. Kriteria pendataannya sebagai berikut: 


$$
\text { Skor }=\frac{\text { jumlah poin yang didapat }}{\text { Jumlah maksimal }} \times 100 \% \text { (Arikunto, 2002) }
$$

2. Lembar Hasil Belajar Siswa. Hasil belajar siswa, yaitu hasil menulis berita siswa. Tes menulis berita tersebut hanya dilakukan satu kali setiap siklus. Tiap-tiap berita yang ditulis siswa oleh guru dinilai berdasarkan aspek yang telah ditentukan. Nilai tersebut diambil dari penjumlahan tiap aspek yang dinilai. Rentangan nilai keseluruhan ditentukan 1 - 100. Berikut ini merupakan aspek dan skor yang diberikan tiap tulisan.

Tabel 1

Aspek Penilaian

\begin{tabular}{cllll}
\hline No & \multicolumn{1}{c}{ Aspek } & \multicolumn{1}{c}{ Deskriptor } & \multicolumn{2}{c}{ Skor } \\
\cline { 3 - 5 } & & & $\mathbf{5}$ & $\mathbf{3}$ \\
\hline 1. & Berita & Ketepatan menulis berita & \\
\hline 2. & Topik/judul & Kesesuaian judul dengan media gambar & \\
\hline 3. & Organisasi & Pengungkapan informasi & \\
\hline 4. & $\begin{array}{l}\text { Pengungkapan dan } \\
\text { pengorganisasian } \\
\text { berita }\end{array}$ & Ketepatan pengungkapan media & \\
\hline 5. & $\begin{array}{l}\text { Penggunaan } \\
\text { bahasa }\end{array}$ & Pengungkapan penggunaan bahasa & \\
\hline
\end{tabular}

Teknik analisis ini menggunakan perhitungan persentase keberhasilan atau ketercapaian siswa dalam menguasai konsep. Perhitungan untuk menyatakan hasil belajar siswa adalah sebagai berikut.

$$
\mathrm{M}=\frac{\sum f_{x}}{\mathrm{~N}}
$$

Keterangan : $\mathrm{M}$ : Mean (Nilai rata-rata)

$\sum f_{x}:$ Jumlah nilai siswa

$\mathrm{N} \quad$ : Jumlah seluruh siswa (Arikunto, 2002)

\section{HASIL PENELITIAN}

\section{Data Hasil Pengamatan Aktivitas Guru dan Aktivitas Siswa Pada Pembelajaran}

\section{Siklus I}

\section{Aktivitas Guru}

Data hasil pengamatan aktivitas guru pada siklus pertama dilakukan selama 2 x 40 menit. Dalam pembelajaran menulis berita dengan menggunakan media gambar tercatat 
beberapa aktivitas guruyang dilakukan baik hal yang positif maupun yang negatif, dinyatakan dalam persentase. Data hasil pengamatan aktivitas guru pada siklus pertama tertera pada tabel berikut:

Tabel 2

Data Aktivitas Guru dalam Pembelajaran Siklus I

\begin{tabular}{|c|c|c|c|}
\hline No & Kategori Aktivitas Guru & $f$ & $\begin{array}{l}\text { Persentase } \\
\text { Kemunculan }\end{array}$ \\
\hline & \multicolumn{3}{|l|}{ Apakah guru: } \\
\hline 1. & Menyampaikan tujuan pembelajaran? & 4 & $13,33 \%$ \\
\hline 2. & Menjelaskan materi pembelajaran? & 4 & $13,33 \%$ \\
\hline 3. & Memberikan contoh media gambar? & 4 & $13,33 \%$ \\
\hline 4. & $\begin{array}{l}\text { Menjelaskan menulis berita dengan menggunakan media } \\
\text { gambar? }\end{array}$ & 3 & $10 \%$ \\
\hline 5. & Menerapkan media gambar pada siswa? & 3 & $10 \%$ \\
\hline 6. & $\begin{array}{l}\text { Memotivasi dan membimbing siswa dalam } \\
\text { menyelesaikan tugas menulis berita? }\end{array}$ & 4 & $13,33 \%$ \\
\hline 7. & $\begin{array}{l}\text { Memberikan umpan balik pada siswa yang bertanya dan } \\
\text { mengklarifikasi materi yang kurang jelas? }\end{array}$ & 2 & $6,67 \%$ \\
\hline 8. & $\begin{array}{l}\begin{array}{l}\text { Menegur siswa yang ramai saat pembelajaran } \\
\text { berlangsung? }\end{array} \\
\end{array}$ & 2 & $6,67 \%$ \\
\hline 9. & Merefleksikan pembelajaran? & 3 & $10,33 \%$ \\
\hline 10. & Memberikan penghargaan kepada siswa & 1 & $3,33 \%$ \\
\hline & Jumlah & 30 & $100 \%$ \\
\hline
\end{tabular}

Berdasarkan hasil pengamatan aktivitas guru dalam pembelajaran menulis berita dengan media gambar, terlihat bahwa aktivitas yang dominan pada pembelajaran siklus pertama adalah menyampaikan tujuan pembelajaran, menjelaskan materi pembelajaran, memberikan contoh media gambar, dan memotivasi siswa dan membimbing siswa dalam menyelesaikan tugas. Keempat aspek tersebut memiliki kemunculan persentase yang sama, yaitu dengan persentase kemunculan 13,33 \%.

Berdasarkan uraian tersebut, terlihat beberapa kriteria yang kurang baik yang terjadi pada pembelajaran siklus I, kriteria yang kurang baik tersebut adalah:

1. Menjelaskan menulis berita dengan media gambar

2. Menerapkan media gambar pada siswa

3. Memberikan umpan balik pada siswa yang bertanya dan mengklarifikasikan materi yang kurang jelas

4. Menegur siswa yang tidak fokus pada materi pelajaran

5. Merefleksikan pembelajaran 
6. Memberikan penghargaan pada siswa

Aspek-aspek diatas merupakan suatu kelemahan yang terjadi pada siklus pertama dan aspek-aspek tersebut dijadikan bahan kajian untuk merefleksi yang akan dilakukan pada siklus kedua.

\section{Aktivitas Siswa}

Dari hasil pengamatan terhadap aktivitas siswa pada siklus I, disajikan pada tabel 3 sebagai berikut:

Tabel 3

Data Aktivitas Siswa dalam Pembelajaran Siklus I

\begin{tabular}{|c|l|c|c|}
\hline No & \multicolumn{1}{|c|}{ Kategori Aktivitas Guru } & $f$ & $\begin{array}{c}\text { Persentase } \\
\text { Kemunculan }\end{array}$ \\
\hline 1. & $\begin{array}{l}\text { Siswa memperhatikan materi pelajaran yang sedang } \\
\text { disampaikan oleh guru? }\end{array}$ & 3 & $12 \%$ \\
\hline 2. & Siswa tidak fokus saat penyampaian materi? & 2 & $8 \%$ \\
\hline 3. & $\begin{array}{l}\text { Apakah siswa mencatat hal-hal yang penting ketika } \\
\text { proses pembelajaran berlangsung? }\end{array}$ & 2 & $8 \%$ \\
\hline 4. & Apakah siswa sering mengajukan pertanyaan? & 3 & $12 \%$ \\
\hline 5. & $\begin{array}{l}\text { Siswa merasa senang dengan media pembelajaran } \\
\text { dalam pembelajaran menulis berita? }\end{array}$ & 4 & $16 \%$ \\
\hline 6. & $\begin{array}{l}\text { Siswa melakukan kegiatan seperti bertanya, baik } \\
\text { pada guru atau siswa }\end{array}$ & 1 & $4 \%$ \\
\hline 7. & Siswa berdiskusi dalam mengerjakan tugas? & 2 & $8 \%$ \\
\hline 8. & $\begin{array}{l}\text { Ada umpan balik saat belajar mengajar } \\
\text { berlangsung? }\end{array}$ & 1 & $4 \%$ \\
\hline 9. & Siswa termotivasi dengan adanya media gambar? & 4 & $16 \%$ \\
\hline 10. & $\begin{array}{l}\text { Siswa merasa nyaman saat pembelajaran } \\
\text { berlangsung? }\end{array}$ & 3 & $12 \%$ \\
\hline & \multicolumn{1}{|c|}{ Jumlah } & $100 \%$ \\
\hline
\end{tabular}

Berdasarkan tabel diatas menunjukkan bahwa aktivitas siswa yang dominan pada siklus pertama ialah merasa senang dengan media pembelajaran menulis berita dan termotivasi dengan media gambar memiliki persentase yang sama yaitu $16 \%$. Dalam hal ini kedua aktivitas tersebut merupakan kegiatan yang menyenangkan dan tampak antusias untuk mengikuti pelajaran menulis berita, karena bagi siswa hal tersebut merupakan pengetahuan baru bagi mereka.

Data hasil belajar siswa dalam pembelajaran menulis berita dengan menggunakan media gambar yang telah dipilih berdasarkan kesepakatan satu kelas. Siklus pertama tersaji pada tabel 4 berikut: 
Tabel 4

Data Hasil Belajar Siswa Siklus I

\begin{tabular}{|c|c|c|}
\hline No. & Nama Siswa & Nilai \\
\hline 1. & ALYA VINDY DAMAYANTI & 64 \\
\hline 2. & ANANDYA PARAHITA TUNJUNGBIRU & 64 \\
\hline 3. & ANDRES FEBRI CHRISTANTO & 52 \\
\hline 4. & ANDRIAN DWI BAITUR RIZKY & 52 \\
\hline 5. & ANGGA RAMA DANI & 60 \\
\hline 6. & AYU SETYA NINGRUM & 68 \\
\hline 7. & DHIVA ANANDHIYAR & 76 \\
\hline 8. & DIAN SAFITRI & - \\
\hline 9. & DIFA ALFI FAUZIAH & 60 \\
\hline 0. & FRANSISKUS REGIS PARTANA & 52 \\
\hline 11. & JEANITA FRISKILA MARLIE & 76 \\
\hline 12. & LANDHU SAQTI JIRANALLA & 68 \\
\hline 13. & LUSIA STEFANY LESTARI & 60 \\
\hline 14. & MARYANA KAMILAH OCTARINE & 60 \\
\hline 15. & MOCHAMMAD ZANUAR N & 52 \\
\hline 16. & MUHAMMAD MIFTACHUL RIZKI & sakit \\
\hline 17. & MUHAN MA'RUF SUSILO & 68 \\
\hline 18. & MUJADID ALDIN ALBASYIR & 60 \\
\hline 19. & NUR LAILY AMALIA & 60 \\
\hline 20. & PUTRI CAHYARANI & 60 \\
\hline 21. & PUTRI PAULINDIA & 68 \\
\hline 22. & RIANA SEPTI WULAN & 52 \\
\hline 23. & RIFQI JULIAN WICAKSANA & 60 \\
\hline 24. & RIKA NOVIA WULANDHARI & 68 \\
\hline 25. & RIZKI RAHMA DINILLAH & 76 \\
\hline 26. & SADDAM SAJEHAN & 60 \\
\hline 27. & SALSABILLA RAHAYU ZAHRA & 60 \\
\hline 28. & TIRTA ADJIE KUSUMABRATA & 64 \\
\hline 29. & TISKA KHOIROTUN NISA & 68 \\
\hline 30. & WAHYU DWI FEBRIANSYAH & 52 \\
\hline 31. & WULAN MAULIDA & - \\
\hline 32. & YURIEKE NISAUL ACHYAR & 68 \\
\hline
\end{tabular}




\begin{tabular}{llc}
\hline 33. & ZAHRA AILLSA ZULKARNAIN & 76 \\
\hline 34. & YULI DYAH DEWI SAVITRI & 60 \\
\hline & JUMLAH & 1944 \\
\hline
\end{tabular}

\section{Data Hasil Pengamatan Aktivitas Guru dan Aktivitas Siswa Pada Siklus II}

\section{Aktivitas Guru}

Data hasil pengamatan aktivitas guru pada siklus II dilakukan selama 2 x 45 menit. Dalam pembelajaran menulis berita dengan menggunakan media gambar tercatat beberapa aktivitas guru yang dilakukan baik aktivitas yang baik maupun yang negatif yang datanya dinyatakan dalam persentase. Data hasil pengamatan aktivitas guru pada siklus II tersaji pada tabel berikut:

Tabel 5

Data Aktivitas Guru dalam Pembelajaran Siklus II

\begin{tabular}{|c|c|c|c|}
\hline No & Kategori Aktivitas Guru & $f$ & $\begin{array}{c}\text { Persentase } \\
\text { Kemunculan }\end{array}$ \\
\hline & \multicolumn{3}{|l|}{ Apakah guru: } \\
\hline 1. & Menyampaikan tujuan pembelajaran? & 4 & $11,76 \%$ \\
\hline 2. & Menjelaskan materi pembelajaran? & 4 & $11,76 \%$ \\
\hline 3. & Memberikan contoh media gambar? & 4 & $11,76 \%$ \\
\hline 4. & $\begin{array}{l}\text { Menjelaskan menulis berita dengan menggunakan } \\
\text { media gambar? }\end{array}$ & 3 & $8,82 \%$ \\
\hline 5. & Menerapkan media gambar pada siswa? & 4 & $11,76 \%$ \\
\hline 6. & $\begin{array}{l}\text { Memotivasi dan membimbing siswa dalam } \\
\text { menyelesaikan tugas menulis berita? }\end{array}$ & 4 & $11,76 \%$ \\
\hline 7. & $\begin{array}{l}\text { Memberikan umpan balik pada siswa yang bertanya } \\
\text { dan mengklarifikasi materi yang kurang jelas? }\end{array}$ & 3 & $8,82 \%$ \\
\hline 8. & $\begin{array}{l}\text { Menegur siswa yang ramai saat pembelajaran } \\
\text { berlangsung? }\end{array}$ & 2 & $5,88 \%$ \\
\hline 9. & Merefleksikan pembelajaran? & 3 & $8,82 \%$ \\
\hline 10. & Memberikan penghargaan kepada siswa & 3 & $8,82 \%$ \\
\hline & Jumlah & 34 & $100 \%$ \\
\hline
\end{tabular}

Berdasarkan hasil pengamatan aktivitas guru dalam pembelajaran menulis berita dengan menggunakan media gambar tersebut, sudah nampak adanya peningkatan pada siklus II ini. Hal itu terlihat aktivitas yang awalnya jarang dilakukan oleh guru. Pada aktivitas menjelaskan dengan menggunakan media gambar, memberikan umpan balik pada siswa yang bertanya dan mengklarivikasikan materi yang kurang jelas, dan memberikan 
penghargaan pada siswa, memiliki persentase kemunculan yang sama dengan besar persentase kemunculan $8,82 \%$.

\section{Aktivitas Siswa}

Dari hasil pengamatan terhadap aktivitas siswa pada siklus II, tersajikan pada tabel 6 sebagai berikut:

Tabel 6

Data Aktivitas Siswa dalam Pembelajaran Siklus II

\begin{tabular}{clcc}
\hline No & \multicolumn{1}{c}{ Kategori Aktivitas Guru } & $f$ & $\begin{array}{c}\text { Persentase } \\
\text { Kemunculan }\end{array}$ \\
\hline 1. & $\begin{array}{l}\text { Siswa memperhatikan materi pelajaran yang sedang } \\
\text { disampaikan oleh guru? }\end{array}$ & 4 & $12,12 \%$ \\
\hline 2. & Siswa tidak fokus saat penyampaian materi? & 3 & $9,09 \%$ \\
\hline 3. & $\begin{array}{l}\text { Apakah siswa mencatat hal-hal yang penting ketika } \\
\text { proses pembelajaran berlangsung? }\end{array}$ & 4 & $12,12 \%$ \\
\hline 4. & Apakah siswa sering mengajukan pertanyaan? & 3 & $9,09 \%$ \\
\hline 5. & $\begin{array}{l}\text { Siswa merasa senang dengan media pembelajaran } \\
\text { dalam pembelajaran menulis berita? }\end{array}$ & 4 & $12,12 \%$ \\
\hline 6. & $\begin{array}{l}\text { Siswa melakukan kegiatan seperti bertanya, baik pada } \\
\text { guru atau siswa lain }\end{array}$ & 3 & $9,09 \%$ \\
\hline 7. & Siswa berdiskusi dalam mengerjakan tugas? & 3 & $9,09 \%$ \\
\hline 8. & Ada umpan balik saat belajar mengajar berlangsung? & 2 & $6,06 \%$ \\
\hline 9. & Siswa termotivasi dengan adanya media gambar? & 4 & $12,12 \%$ \\
\hline 10. & Siswa merasa nyaman saat pembelajaran berlangsung? & 3 & $9,09 \%$ \\
\hline & \multicolumn{1}{c}{ Jumlah } & 33 & $100 \%$ \\
\hline
\end{tabular}

Dari uraian diatas, terlihat beberapa kriteria yang masih perlu adanya peningkatan antara lain:

1. Berdiskusi diluar materi yang disampaikan

2. Sering mengajukan pertanyaan

3. Melakukan kegiatan seperti diskusi, bertanya kepada guru maupun kepada siswa

4. Berdiskusi dalam mengerjakan tugas

5. Dalam proses belajar mengajar selalu ada umpan balik

6. Siswa merasa nyaman saat proses pembelajaran berlangsung

Aspek diatas merupakan suatu kelemahan yang terjadi pada siklus II dan aspekaspek tersebut dijadikan bahan kajian untuk refleksi yang akan dilakukan pada siklus III. Data Hasil Belajar Siswa Siklus II 
Data hasil belajar siswa dalam pembelajaran menulis berita dengan menggunakan media gambar yang telah ditentukan oleh guru, hasil siklus II ini tersaji pada tabel 7 berikut:

Tabel 7

Data Hasil Belajar Siswa Siklus II

\begin{tabular}{|c|c|c|}
\hline No. & Nama Siswa & Nilai \\
\hline 1. & ALYA VINDY DAMAYANTI & 60 \\
\hline 2. & ANANDYA PARAHITA TUNJUNGBIRU & 68 \\
\hline 3. & ANDRES FEBRI CHRISTANTO & 68 \\
\hline 4. & ANDRIAN DWI BAITUR RIZKY & 68 \\
\hline 5. & ANGGA RAMA DANI & 76 \\
\hline 6. & AYU SETYA NINGRUM & 76 \\
\hline 7. & DHIVA ANANDHIYAR & 76 \\
\hline 8. & DIAN SAFITRI & 76 \\
\hline 9. & DIFA ALFI FAUZIAH & 60 \\
\hline 0. & FRANSISKUS REGIS PARTANA & 60 \\
\hline 11. & JEANITA FRISKILA MARLIE & 84 \\
\hline 12. & $\begin{array}{l}\text { LANDHU SAQTI JIRANALLA } \\
\end{array}$ & 76 \\
\hline 13. & LUSIA STEFANY LESTARI & Sakit \\
\hline 14. & MARYANA KAMILAH OCTARINE & 76 \\
\hline 15. & MOCHAMMAD ZANUAR N & 68 \\
\hline 16. & MUHAMMAD MIFTACHUL RIZKI & Sakit \\
\hline 17. & MUHAN MA'RUF SUSILO & 76 \\
\hline 18. & MUJADID ALDIN ALBASYIR & 68 \\
\hline 19. & NUR LAILY AMALIA & 68 \\
\hline 20. & PUTRI CAHYARANI & 86 \\
\hline 21. & PUTRI PAULINDIA & 76 \\
\hline 22. & RIANA SEPTI WULAN & 68 \\
\hline 23. & RIFQI JULIAN WICAKSANA & 68 \\
\hline 24. & RIKA NOVIA WULANDHARI & 76 \\
\hline 25. & RIZKI RAHMA DINILLAH & 84 \\
\hline 26. & SADDAM SAJEHAN & 68 \\
\hline 27. & SALSABILLA RAHAYU ZAHRA & 60 \\
\hline 28. & TIRTA ADJIE KUSUMABRATA & 68 \\
\hline 29. & TISKA KHOIROTUN NISA & 76 \\
\hline 30. & WAHYU DWI FEBRIANSYAH & 60 \\
\hline 31. & WULAN MAULIDA & - \\
\hline 32. & YURIEKE NISAUL ACHYAR & Izin \\
\hline 33. & ZAHRA AILLSA ZULKARNAIN & 84 \\
\hline \multirow[t]{2}{*}{34.} & YULI DYAH DEWI SAVITRI & 68 \\
\hline & JUMLAH & 2146 \\
\hline
\end{tabular}




\section{Data hasil Pengamatan Aktivitas Guru dan Siswa pada pembelajaran Siklus III}

\section{Aktivitas Guru}

Data hasil pengamatan aktivitas guru pada siklus II dilakukan selama 2 x 40 menit. Dalam pembelajaran menulis berita dengan menggunakan media gambar tercatat beberapa aktivitas guru yang dilakukan baik aktivitas yang positif maupun aktivitas negatif yang dinyatakan dalam persentase

Tabel 8

Data Aktivitas Guru dalam Pembelajaran Siklus III

\begin{tabular}{|c|c|c|c|}
\hline No & Kategori Aktivitas Guru & $f$ & $\begin{array}{l}\text { Persentase } \\
\text { Kemunculan }\end{array}$ \\
\hline & \multicolumn{3}{|l|}{ Apakah guru: } \\
\hline 1. & Menyampaikan tujuan pembelajaran? & 4 & $10,53 \%$ \\
\hline 2. & Menjelaskan materi pembelajaran? & 4 & $10,53 \%$ \\
\hline 3. & Memberikan contoh media gambar? & 4 & $10,53 \%$ \\
\hline 4. & $\begin{array}{l}\text { Menjelaskan menulis berita dengan menggunakan } \\
\text { media gambar? }\end{array}$ & 4 & $10,53 \%$ \\
\hline 5. & Menerapkan media gambar pada siswa? & 4 & $10,53 \%$ \\
\hline 6. & $\begin{array}{l}\text { Memotivasi dan membimbing } \\
\text { menyelesaikan tugas menulis berita? }\end{array}$ & 4 & $10,53 \%$ \\
\hline 7. & $\begin{array}{l}\text { Memberikan umpan balik pada siswa yang bertanya } \\
\text { dan mengklarifikasi materi yang kurang jelas? }\end{array}$ & 4 & $10,53 \%$ \\
\hline 8. & 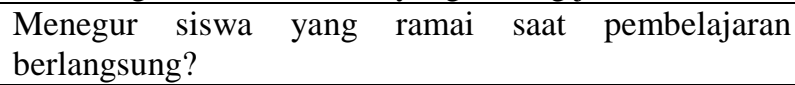 & 3 & $7,90 \%$ \\
\hline 9. & Merefleksikan pembelajaran? & 3 & $7,90 \%$ \\
\hline 10. & Memberikan penghargaan kepada siswa & 4 & $10,53 \%$ \\
\hline & Jumlah & 38 & $100 \%$ \\
\hline
\end{tabular}

Berdasarkan hasil pengamatan aktivitas guru dalam pembelajaran menulis berita dengan menggunakan media gambar siklus III diatas sudah tampak sebagian besar aktivitas sudah dilakukan oleh guru.

Table 9

Data Aktivitas Siswa dalam Pembelajaran Siklus III

\begin{tabular}{clcc}
\hline No & \multicolumn{1}{c}{ Kategori Aktivitas Guru } & $f$ & $\begin{array}{c}\text { Persentase } \\
\text { Kemunculan }\end{array}$ \\
\hline 1. & $\begin{array}{l}\text { Siswa memperhatikan materi pelajaran yang sedang } \\
\text { disampaikan oleh guru? }\end{array}$ & 4 & $10,81 \%$ \\
\hline 2. & Siswa tidak fokus saat penyampaian materi? & 4 & $10,81 \%$ \\
\hline 3. & $\begin{array}{l}\text { Apakah siswa mencatat hal-hal yang penting ketika } \\
\text { proses pembelajaran berlangsung? }\end{array}$ & 3 & $8,11 \%$ \\
\hline 4. & Apakah siswa sering mengajukan pertanyaan? & 4 & $10,81 \%$ \\
\hline 5. & $\begin{array}{l}\text { Siswa merasa senang dengan media pembelajaran dalam } \\
\text { pembelajaran menulis berita? }\end{array}$ & 4 & $10,81 \%$ \\
\hline 6. Siswa melakukan kegiatan seperti bertanya, baik pada & 4 & $10,81 \%$ \\
\hline
\end{tabular}




\begin{tabular}{|c|c|c|c|}
\hline \multicolumn{4}{|c|}{ guru atau siswa lain } \\
\hline 7. & Siswa berdiskusi dalam mengerjakan tugas? & 3 & $8,11 \%$ \\
\hline 8. & Ada umpan balik saat belajar mengajar berlangsung? & 3 & $8,11 \%$ \\
\hline 9. & Siswa termotivasi dengan adanya media gambar? & 4 & $10,81 \%$ \\
\hline 10. & Siswa merasa nyaman saat pembelajaran berlangsung? & 4 & $10,81 \%$ \\
\hline & Jumlah & 37 & $100 \%$ \\
\hline
\end{tabular}

Berdasarkan hasil pengamatan aktivitas siswa dalam pembelajaran menulis berita dengan menggunakan media gambar pada siklus III ini aktivitas siswa mengalami banyak peningkatan.

\section{Hasil Belajar Siswa Siklus III}

Data hasil belajar siswa dalam pembelajaran menulis berita dengan menggunakan media gambar yang telah ditentukan oleh guru pada siklus III ini disajikan pada tabel 10 berikut:

Tabel 10

Data Hasil Belajar Siswa Siklus III

\begin{tabular}{clc}
\hline No. & \multicolumn{1}{c}{ Nama Siswa } & Nilai \\
\hline 1. & ALYA VINDY DAMAYANTI & 68 \\
\hline 2. & ANANDYA PARAHITA TUNJUNGBIRU & 76 \\
\hline 3. & ANDRES FEBRI CHRISTANTO & 76 \\
\hline 4. & ANDRIAN DWI BAITUR RIZKY & 76 \\
\hline 5. & ANGGA RAMA DANI & 84 \\
\hline 6. & AYU SETYA NINGRUM & 84 \\
\hline 7. & DHIVA ANANDHIYAR & 84 \\
\hline 8. & DIAN SAFITRI & 76 \\
\hline 9. & DIFA ALFI FAUZIAH & 76 \\
\hline 0. & FRANSISKUS REGIS PARTANA & 68 \\
\hline 11. & JEANITA FRISKILA MARLIE & 92 \\
\hline 12. & LANDHU SAQTI JIRANALLA & 84 \\
\hline 13. & LUSIA STEFANY LESTARI & 76 \\
\hline 14. & MARYANA KAMILAH OCTARINE & 84 \\
\hline 15. & MOCHAMMAD ZANUAR N & 76 \\
\hline 16. & MUHAMMAD MIFTACHUL RIZKI & 76 \\
\hline 17. & MUHAN MA'RUF SUSILO & 84 \\
\hline 18. & MUJADID ALDIN ALBASYIR & 76 \\
\hline 19. & NUR LAILY AMALIA & 76 \\
\hline 20. & PUTRI CAHYARANI & 84 \\
\hline 21. & PUTRI PAULINDIA & 84 \\
\hline 22. & RIANA SEPTI WULAN & 76 \\
\hline 23. & RIFQI JULIAN WICAKSANA & 76 \\
\hline 24. & RIKA NOVIA WULANDHARI & 84 \\
\hline 25. & RIZKI RAHMA DINILLAH & 92 \\
\hline 26. & SADDAM SAJEHAN & 76 \\
\hline & & \\
\hline & & \\
\hline
\end{tabular}




\begin{tabular}{clc}
\hline 27. & SALSABILLA RAHAYU ZAHRA & 76 \\
\hline 28. & TIRTA ADJIE KUSUMABRATA & 76 \\
\hline 29. & TISKA KHOIROTUN NISA & 84 \\
\hline 30. & WAHYU DWI FEBRIANSYAH & 76 \\
\hline 31. & WULAN MAULIDA & 84 \\
\hline 32. & YURIEKE NISAUL ACHYAR & 84 \\
\hline 33. & ZAHRA AILLSA ZULKARNAIN & 92 \\
\hline 34. & YULI DYAH DEWI SAVITRI & 76 \\
\hline & JUMLAH & 2712 \\
\hline
\end{tabular}

\section{PEMBAHASAN}

Rata-rata nilai siswa pada pembelajaran siklus pertama sebagai berikut, dapat diketahui bahwa rata-rata nilai siswa dalam pembelajaran menulis teks berita dengan pendekatan QuantumLearning siklus pertama ialah 62,92. Nilai rata-rata hasil belajar menulis teks berita siswa siklus pertama tersebut belum sesuai dengan pencapaian indikator keberhasilan hasil belajar siswa. Pencapaian indikator keberhasilan siswa dikatakan tuntas apabila nilai rata-rata siswa belajar menulis teks berita siswa mencapai nilai 70 .

Rata-rata nilai siswa pada pembelajaran siklus kedua sebagai berikut, dapat diketahui bahwa rata-rata nilai siswa dalam pembelajaran menulis teks berita dengan media gambar pada pembelajaran siklus kedua ialah 72. Nilai rata-rata menulis teks berita siswa siklus kedua lebih baik dibandingkan dengan nilai rata-rata hasil belajar siswa pada pembelajaran siklus pertama. Artinya adalah nilai rata-rata hasil belajar siswa pada pembelajaran siklus kedua mengalami peningkatan.

Rata-rata nilai siswa pada pembelajaran siklus ketiga sebagai berikut, dapat diketahui bahwa rata-rata nilai siswa dalam pembelajaran menulis teks berita dengan media gambar pada pembelajaran siklus ketiga ialah 80. Nilai rata-rata hasil belajar menulis teks berita siswa siklus ketiga ini ialah lebih baik dibandingkan dengan nilai rata-rata hasil belajar menulis teks berita siswa siklus pertama dan siklus kedua. Dengan kata lain, nilai rata-rata hasil belajar menulis teks berita siswa siklus ketiga mengalami peningkatan dibandingkan siklus pertama dan kedua. 


\section{SIMPULAN}

Berdasarkan penelitian yang dilakukan selama tiga siklus, dapat diperoleh kesimpulan sebagai berikut:

1. Berdasarkan hasil pengamatan, aktivitas guru dalam pembelajaran menulis berita melalui pendekatan quantum learning dengan media gambar. Dapat disimpulkan bahwa kualitas aktivitas guru pelaksanaan pembelajaran tiap siklusnya mengalami peningkatan kualitas aktivitas guru didasarkan atas kemunculan persentase kemunculan aktivitas guru di tiap siklusnya.

2. Berdasarkan hasil pengamatan, aktivitas siswa dalam pembelajaran menulis teks berita melalui pendekatan quantum learning dengan media gambar menunjukkan peningkatan kualitas aktivitas siswa dalam tiap siklusnya. Peningkatan kualitas aktivitas siswa dalampembelajaran menulis teks berita didasarkan atas kemunculan persentase aktivitas siswa di tiap siklusnya.

3. Berdasarkan pencapaian hasil belajar siswa dalam pembelajaran menulis teks berita dengan media gambar dapat disimpulkan bahwa hasil belajar siswa dari tiap siklus pembelajaran menunjukkan peningkatan hal itu dapat diketahui dari perolehan nilai rata-rata siswa pada kondisi awal sampai pada pembelajaran siklus terakhir atau siklus ketiga menunjukkan peningkatan nilai rata-rata, dan keberhasilan belajar siswa itu dicapai pada pembelajaran siklus ketiga.

\section{DAFTAR PUSTAKA}

Arikunto, Suharsimi. (2002). Prosedur Penelitian Suatu Pendekatan Praktik. Jakarta: Rineka Cipta.

De Porter, Bobbi dan Harnacki. (2002). Quantum Learning: Membiasakan Belajar Nyaman dan Menyenangkan. Terjemahan oleh Hernowo. Bandung: Kaifa.

Suyatno. (2004). Permainan Pendukung Pembelajaran Bahasa Indonesia. Surabaya: SIC.

Moleong. (2003). Metode Penelitian. Jakarta: Pustaka Setia

Tarigan, Henru Guntur. (1982). Menulis Sebagai Suatu Keterampilan. Bandung: Angkasa. 